\title{
Impact of the parasitic wasp Nasonia spp. (Walker, 1836) Hymenoptera: Pteromalidae) on populations of bird blowflies Protocalliphora spp. Hough, 1899 (Diptera: Calliphoridae)
}

\begin{abstract}
In this work we focused on the prevalence of infection of Nasonia spp. ${ }^{1}$ in pupae of Protocalliphora spp. collected from nests $(n=160)$ of different avian hosts from different sites in Slovakia. Our research was focused on the impact of this parasitoid wasp on bird blowflies under natural conditions. We studied its occurrence, which was $83.125 \%$ of all nests where bird blowflies were present. The consequent mortality of host populations was $61.087 \%$ with the number of wasps localized in individual pupa estimated on almost 23 . The aim of this work was to show that parasitoid wasp Nasonia spp. significantly affects populations of Protocalliphora spp. under natural conditions and that they have important role in regulation of population of bird blowflies.
\end{abstract}

Volume 7 Issue I - 2019

\author{
Jan Jamriska, ${ }^{1,2}$ Terezia Lucenicova $^{2}$ \\ ITierklinik Zistersdorf, Austria \\ ${ }^{2}$ Wildlife Rescue and Rehabilitation Center, Slovakia
}

Correspondence: Jan Jamriska,Wildlife Rescue and Rehabilitation Center-Into the Wild/Navrat do divociny, Borinka 199, 90032 Borinka, Slovakia, Email jan.jamriska5@gmail.com

Received: September 21, 2017 | Published: January 04, 2019

Keywords: Nasonia spp., Protocalliphora spp., pupae, parasitoid wasp, Slovakia

\section{Introduction}

The immature stages of a large number of blowflies are parasitized by parasitic wasps with local or cosmopolitan distribution. ${ }^{2-4}$ Several species parasitize pupae of bird blowflies by penetrating the host pupae. One such group of parasitic wasps, are solitary or gregarious ectophagous parasitoids from the Pteromalidae family. The most commonly world-wide distributed is Nasonia vitripennis. Its life cycle is well established because it has been widely used in genetic and field studies ${ }^{5,6}$ and pupal parasitoids have attracted a lot of attention because of their potential control of house and stable flies in farms. ${ }^{1}$ A female parasite with matured eggs drills through the host pupae with her ovipositor laying eggs externally on the pupa and injects a substance, to narcotize or kill the host. The female feeds on haemolymph from the host tissues. The parasite larvae feed throughout the three instars, and then pupate, and the adult's enclose approximately 24 hours before biting one or more holes and emerging from the host pupa. The same emergence hole is used by successive emerges, and the males usually emerge before the females. ${ }^{6-8}$ The females do not drill pupae which have an emergence hole of a fly or parasites, otherwise it drills without laying eggs if the host is not pupated or is dead or contains late instars parasite larvae or adults. ${ }^{7}$ Temperature and humidity are important factors in the survival of the wasp, and in unsuitable conditions for further development the third instar can be diapaused. Previously there has been little information about the parasitization of bird blowflies under natural conditions. Eshuis van der Voet ${ }^{9}$ recorded that $48.8 \%$ of Protocalliphora spp. pupae were infested by this parasitic wasp in Parus major nests in Holland, while in the USA, $20.1 \%$ of these species pupae found to be parasitized by the same wasp. ${ }^{2}$ The parasitization of $N$. vitripennis reported by Peters ${ }^{4}$ was $42.1 \%$ in Protocalliphora azurea (cele meno) pupae and $15.8 \%$ in Protocalliphora falcozi (cele meno) pupae.

\section{Material and methods}

We collected 2300 specimens of pupae from 160 bird nests infected by Protocalliphora spp. from western Slovakia during the 2011-2014 season. These nests were collected after nestlings fledged, carefully examined, and pupae were reared, observed under a stereomicroscope and then divided into groups. At first, there was a group that contained pupae specimens where Protocalliphora spp. flies emerged and no parasitoids were found. The second one consisted of specimens which where parasitized by parasitoid wasps. Presence of parasitoids was determined by exit holes and enclosed pupae were dissected and inspected for wasps. All stages of parasitic wasp if present were counted. These results were statistically analyzed, and compared to accessible records. The parasitic wasp was indentified according to Bouček' ${ }^{10}$ taxonomic key. Some parasitized pupae were kept under laboratory conditions, $\left(\mathrm{T}=26^{\circ} \mathrm{C}\right.$, humidity $\left.65 \%\right)$ until wasps emerged to identify how many adult specimens were able to develop and emerge from one particular puparium.

\section{Results}

During the seasons 2011-2014, 160 bird nests parasitized by bird blowflies were collected from western Slovakia, whereas $83.125 \%$ (133) of these nests, were predated with parasitoid wasp Nasonia spp. 2300 pupae specimens were reared from all these nests (133). Only $38.913 \%$ (895) of adult flies emerged from nests where Nasonia spp. was found. The rest of pupae $61.087 \%$ (1405) were predated by parasitoid wasp (872) or did not develop from other differing reasons (533).Therefore the mortality rate of Protocalliphora spp. pupae directly caused by Nasonia spp. was estimated on $37.913 \%$ and causes such as temperature or environmental factors resulted in a further $23.174 \%$ cases. We also recorded the number of parasitoid wasps in one pupa. 50 pupae were held under laboratory conditions to let the wasps develop and emerge Almost $40 \%$ of selected puparia were predated by parasitoid wasps The average number of adult Nasonia specimens emerging from one pupa was $22.7 \pm 9.1$ while the $\min =14$ and the $\max =49$ specimens.

\section{Discussion}

Numerous parasitoid species attack more than one host species, 
and in many cases, these hosts vary in suitability for the parasitoid development. ${ }^{11,12}$ The most common polyphagous pupal parasite $N$. vitripennis is found in North America, together with two other pteromalids $N$. giraulti and $N$. longicornis. ${ }^{11} N$. vitripennis is a generalist and parasitize a wide range of fly hosts, including blowflies, flesh flies and houseflies. ${ }^{11}$ Other rarer parasitoid wasps recorded from Protocalliphora spp puparia, include those from the near arctic region; namely pteromalid Morodora armata, ${ }^{13}$ pteromalid Dibrachys cavus $^{1}$ and encyrtid Tachinaephagus zealandicus. ${ }^{14}$ Additionally, the pteromalid Muscidifurax raptor ${ }^{15}$ was recorded in the bird nests containing Protocalliphora spp. but definite association with it was not established. ${ }^{2,3}$ The most important parasitic wasp which attacks the pupae of bird blowflies in Europe is $N$. vitripenis. ${ }^{4,16,17}$ In contrast to much laboratory research on this species there is only little known about its biology under natural conditions The clutch number in Protocalliphora pupae is ranging from 4 to 24 wasps per host. ${ }^{18}$ Draber ${ }^{17}$ reported that in 7 puparia 140 adults of Nasonia spp. were found ( $\min =11$ and $\max =44$ specimens). Our research showed that the average number of adult Nasonia specimens emerging from one pupa was almost 23, and this is consistent with King and Skinners' reports. Nasonia females probably regulate the number of eggs laid during one period and ssupernumerary larvae are eliminated by starvation. Eshuis van der Voet $^{9}$ recorded $48.8 \%$ of Protocalliphora pupae infested by this parasitic wasp in Parus major nests in Holland, while in the USA, $20.1 \%$ of these species pupae found to be parasitized by the same wasp. ${ }^{2}$ The parasitization of Nasonia vitripennis reported by Peters $^{4}$ was $42.1 \%$ in Protocalliphora azurea puparia and $15.8 \%$ in Protocalliphora falcozi puparia. In this study we found that parasitism of Protocalliphora spp. pupae, directly attributable to Nasonia spp. occurred in $37.913 \%$ of birds nests where this parasitoid wasp was present. Additionally, $83.125 \%$ of the total nests found, were subject to parasitoid predation. It seems that parasitoid wasp Nasonia spp. plays an important role in regulation of population of bird blowflies in birds nests and only $38.913 \%$ adult flies emerge from pupae present in nests. Also specific host ecology can be something that plays its role in parasitoid predation.

\section{Acknowledgments}

We would like to thank to anonymous referees for their remarks to this manuscript.

\section{Conflicts of interest}

Authors declare that there is no conflicts of interest.

\section{References}

1. Birkemoe T, Soleng A, Riddervold KW. Use of the parasitoid wasp Nasonia vitripennis (Walker, 1836) in the control of Musca domestica L., 1758 and Stomox vs calcitrans (L., 1758) on two Norwegian pig farms. Norw J Entomol. 2004;51:165-173.

2. Gold CS, Dahlsten DL. Prevalence, habitat selection and biology of Protocalliphora (Diptera: Calliphoridae) found in nests of Mountain and Chestnut-backed Chickadees in California. Hilgardia. 1989;57(2):1-19.
3. Sabrosky CW, Bennett GF, Whitworth TL. Bird Blow Flies (Protocalliphora) in North America (Diptera: Calliphoridae), with notes on the Palearctic species. Washington: Smithsonian Institute Press; 1989. $312 \mathrm{p}$.

4. Peters SR. Interactions between hosts and parasitoids: food web structure, host spectra and host finding using the example of species of bird nests (Insecta: Diptera: Cyclorrhapha and Hymenoptera: Chalcidoidea). Dissertation. The Faculty of Mathematics, Computer Science and Natural Sciences at the University of Hamburg; 2006. 159 p.

5. Beard RL. Parasites of muscoid flies. Bull World Health Organ. 1964;31:491-493.

6. Werren JH. Brood size and sex ratio regulation in the parasitic wasp Nasonia vitripennis (Walker)(Hymenoptera: Pteromalidae). Neth J Zool. 1984;34(2):123-143.

7. Whiting RA. The biology of the parasitic wasp Mormoniella vitripennis [Nasonia brevicornis] (Walker). The Quarterly Review of Biology. 1967;42(3):333-406.

8. Wylie HG. Factors that affect host finding by Nasonia vitripennis (Walk.)(Hymenoptera: Pteromalidae). The Canadian Entomologist. 1958;90(10):597-608.

9. Eshuis-van der Voet CW. Parasitism by Protocalliphora sp. Verh Akad Wet Amst Afd Natuurk Tweede Reeks. 1975;66:81-84.

10. Bouček Z. White-winged Hens - Hymenoptera. In: Kratochvil J, (ed). Key of the animals ČSR 2. Praha: ČSAV; 1957.747 p.

11. Darling CD, Werren JH. Biosystematics of Nasonia (Hymenoptera: Pteromalidae): Two New Species Reared from Birds' Nests in North America. Ann Entomol Soc Am. 1990;83(3):352-370.

12. Abraham R, Ralph SP. Nest boxes as a habitat for insects, especially flies and their parasitic wasps. Ornithological. 2008;46:195-205.

13. Burks BD. Torymidae (Agaoninae) and all other families of Chalcidoidea (excluding Encyrtidae). In: Krombein KV, Hurd, PD, Smith DR, et al. (eds). Catalogue of Hymenoptera in America north of Mexico. Washington: Smithsonian Institute Press; 1979. 748-749 p.

14. Werren JH. A model for sex ratio selection in parasitic wasps: Local mate competition and host quality effects. Neth J Zool. 1984;34(1):81-96.

15. Saunders DS, Sutton D, Jarvis RA. The effect of host species on diapause induction in Nasonia vitripennis. J Insect Physiol. 1970;16(3):405-416.

16. Erzinclioglu YZ. A new parasite record for Protocalliphora azurea (Fall.) (Diptera, Calliphoridae). Entomol mon Mag. 1984;120-172p.

17. Draber-Mońko A. Protocalliphora azurea (Fall.) (Diptera: Calliphoridae) and other insects found in nests of Sparrows, Passer domesticus (L.) and Passer montanus (L.) in the vicinity of Warsaw. International Studies on Sparrows. 1997;22-23:3-10.

18. King BH, Skinner SW. Sex ratio in a new species of Nasonia with fullywinged males. Evolution. 1991;45(1):225-228. 